$1-1-2011$

\title{
Defining the phenotypes of sickle cell disease.
}

Samir K. Ballas

Thomas Jefferson University

Follow this and additional works at: https://jdc.jefferson.edu/medfp

Part of the Medical Genetics Commons

Let us know how access to this document benefits you

\section{Recommended Citation}

Ballas, Samir K., "Defining the phenotypes of sickle cell disease." (2011). Department of

Medicine Faculty Papers. Paper 64.

https://jdc.jefferson.edu/medfp/64

This Article is brought to you for free and open access by the Jefferson Digital Commons. The Jefferson Digital Commons is a service of Thomas Jefferson University's Center for Teaching and Learning (CTL). The Commons is a showcase for Jefferson books and journals, peer-reviewed scholarly publications, unique historical collections from the University archives, and teaching tools. The Jefferson Digital Commons allows researchers and interested readers anywhere in the world to learn about and keep up to date with Jefferson scholarship. This article has been accepted for inclusion in Department of Medicine Faculty Papers by an authorized administrator of the Jefferson Digital Commons. For more information, please contact: JeffersonDigitalCommons@jefferson.edu. 


\title{
As submitted to:
}

\author{
Hemoglobin
}

\section{And later published as:}

\section{DEFINING THE PHENOTYPES OF SICKLE CELL DISEASE}

\author{
Volume 35, Issue 5-6, October 2011, Pages 511-519
}

\section{DOI: 10.3109/03630269.2011.610477}

PRESENTED AT THE

INTERNATIONAL CONFERENCE

ON HEMOGLOBIN DISORDERS

KUWAIT, February 5-7th, 2011

Samir K. Ballas

Cardeza Foundation, Department of Medicine, Jefferson Medical College, Thomas Jefferson University, Philadelphia, Pennsylvania, USA

Declaration of Interest: The authors report no conflicts of interest. The authors alone are responsible for the content and writing of this article.

Received 23 March 2011; Accepted 23 March 2011.

Address correspondence to Samir K. Ballas, M.D., F.A.C.P., Cardeza Foundation, 1015 Walnut Street, Philadelphia, PA 19107, USA; Tel.: +215-955-5266, extension: 98686; Fax: +856-7950809; E-mail: samir.ballas@jefferson.edu

SHORT TITLE: Defining the Phenotypes of Sickle Cell Disease 
PRESENTED AT THE

INTERNATIONAL CONFERENCE

ON HEMOGLOBIN DISORDERS

KUWAIT, February 5-7th, 2011

\title{
DEFINING THE PHENOTYPES OF SICKLE CELL DISEASE
}

\author{
Samir K. Ballas \\ Cardeza Foundation, Department of Medicine, Jefferson Medical College, Thomas Jefferson \\ University, Philadelphia, Pennsylvania, USA
}

\begin{abstract}
The sickle cell gene is pleiotropic in nature. Although it is a single gene mutation, it has multiple phenotypic expressions that constitute the complications of sickle cell disease. The frequency and severity of these complications vary considerably both latitudinally in patients and longitudinally in the same patient over time. Thus, complications that occur in childhood may disappear, persist or get worse with age. Dactylitis and stroke, for example, occur mostly in childhood, whereas leg ulcers and renal failure typically occur in adults. It is essential that the phenotypic manifestations of sickle cell disease be defined accurately so that communication among providers and researchers facilitates the implementation of appropriate and cost-effective diagnostic and therapeutics modalities. The aim of this review is to define the complications that are specific to sickle cell disease based on available evidence in the literature and the experience of hematologists in this field.
\end{abstract}

Keywords Sickle cell disease, Sickle cell anemia, Phenotype, Genotype, Definition, Complications

\section{INTRODUCTION}

Dictionaries define a definition as "an exact statement or description of the nature, scope, or meaning of something." Having such a statement about the complications of sickle cell disease facilitates communication among physicians, investigators, ancillary medical staff, insurers, the public, patients and their families. Until recently, however, accepted definitions of the complications of sickle cell disease did not exist. This state of affairs made it difficult to establish cost-effective diagnostic and therapeutic approaches to these complications. To that end, a conservative cautious provider, for example, may confuse acute bronchitis with acute chest syndrome (ACS) and treat with exchange blood transfusion unnecessarily. On the other hand, some providers may under estimate a serious complication of sickle cell disease and delay the institution of aggressive therapeutic modalities as needed. In order to fill this gap, the comprehensive sickle cell centers supported by the National Institutes of Health (NIH) published definitions of the phenotypic complications of sickle cell disease $(1,2)$. These were based on whatever evidence that was available in the literature and the experience of a large number of hematologists taking care of patients with sickle cell disease for decades. In that publication each complication included its 1) definition, 2) diagnostic criteria, 3) severity index if applicable, 4) 
classification if available, and 5) references. In this presentation I will review the definition of those complications that are specific to sickle cell disease with emphasis on those not described by my colleagues in this Conference Proceedings. Moreover, I will describe the newly described complication of sickle cell anemia, neurocognitive impairment that was not described previously.

\section{Genetic and Epigenetic Factors}

The phenotype of a complication depends on genetic and epigenetic factors. Genetic factors include the mutation or mutations of the gene in question, pleiotropy of the gene if applicable, the presence or absence of gene modifiers (also known as epistatic genes) and co-inheritance of related genes. Thus, sickle cell anemia is due to a single mutation in the $\beta$-globin gene of the hemoglobin $(\mathrm{Hb})$ molecule resulting in the replacement of glutamic acid with valine at position 6 of the $\beta$-globin polypeptide. $\mathrm{Hb} \mathrm{C}$-Harlem, (also known as $\mathrm{Hb} \mathrm{C}$-Georgetown) on the other hand, has two mutations on the same $\beta$-globin chain including the same sickle mutation described above and another mutation at position 73 of the $\beta$-globin chain with aspartic acid replacing aspargine (3). The sickle gene, in addition, is pleiotropic, meaning that although it is a single gene mutation it has multiple phenotypic effects (4). The co-inheritance of $\mathrm{Hb} \mathrm{C}$ or $\beta$ thalassemia $(\beta$-thal) genes with the sickle cell gene affects the phenotypic expression of this combination. A complex network of gene modifiers seems to affect the phenotypic expression of the sickle cell complications. The Central African Republic (CAR) $\beta$ haplotype, for example, seems to be associated with more severe sickle cell disease (5).

Epigenetic factors that could affect phenotypic expression include the environment, aging, drugs/pharmaceuticals and diet (6). The exact mechanism of action of epigenetic factors at the molecular level is not well known. It seems that some drugs may cause methylation or demethylation of DNA or modification of histones resulting in activation or deactivation of certain genes that could affect the phenotypic expression of the gene in question (6).

\section{COMPLICATIONS OF SICKLE CELL DISEASE}

Complications of sickle cell disease include four sets of clinical adverse effects: 1) pain syndromes; 2) hemolytic anemia and its sequelae; 3) organ damage/failure, and 4) co-morbid conditions (7). In this review I will focus on hemolytic anemia and organ damage as shown in Table 1.

Hemolytic Anemia and its Sequelae

Aplastic crisis is transient, total or partial suppression of erythropoiesis characterized by a decrease in the Hb level and reticulocyte count, or in the number of red blood cell precursors in the bone marrow. The decrease in $\mathrm{Hb}$ should be $\geq 20 \%$ from baseline and the absolute reticulocyte count should be $<50,000$ or be disproportionately low with respect to the $\mathrm{Hb}$ level (8).

Hyperhemolysis

Marked drop in $\underline{\mathrm{Hb}}$ with evidence of increased red blood cell destruction in the absence of other 
identifiable causes such as splenic or hepatic sequestration. The decrease in $\mathrm{Hb}$ should be $\geq 20 \%$ from baseline and the increase in reticulocyte by $25 \%$ or presence of nucleated RBC in the peripheral smear. Moreover, there should be evidence of hemolysis [increased lactate dehydrogenase (LDH), unconjugated bilirubin, or aspartate aminotransferase (AST)], compared with baseline WITHOUT recovery from bone marrow suppression (9).

\section{Acute Splenic Sequestration}

Rapid intrasplenic trapping of cellular elements of the blood, which causes a precipitous fall in $\mathrm{Hb}$ level and is often associated with a relative or absolute thrombocytopenia and hypovolemia. The decrease in $\mathrm{Hb}$ should be $\geq 20 \%$ from baseline and there should be evidence of increased erythropoeisis such as increased reticulocyte count $\geq 25 \%$ and an acutely enlarged spleen $(\geq 2 \mathrm{~cm})$ (10).

Functional Asplenia

Absent or markedly decreased splenic function in the absence of a surgical or congenital cause. There should be increase in pit count $(\geq 3.5 \%)$, or presence of Howell-Jolly bodies or lack of radionuclide uptake on liver/spleen scan (11).

\section{Hyperviscosity}

Whole blood viscosity is a function of both the number and deformability of erythrocytes, as well as of the quantity and nature of plasma proteins. In sickle cell disease, viscosity is dominated by $\mathrm{Hb} \mathrm{S}$ gelation and the presence of dense sickle cells. The hyperviscosity syndrome in sickle cell disease (and other hemoglobinopathies) occurs most frequently post-transfusion (12).

\section{Transfusional Hemosiderosis}

Transfusional hemosiderosis or iron overload refers to an increase in total body iron due to multiple blood transfusions of $\geq 20$ units or $\geq 200 \mathrm{~mL} / \mathrm{kg}$ of red blood cells and serum ferritin level of $>1000 \mathrm{ng} / \mathrm{mL}$ and transferrin saturation $>50 \%$ on $\geq 3$ serial determinations in the steady state or measurement of abnormally increased iron by liver biopsy, SQUID, magnetic resonance imaging (MRI) T2* or Ferriscan (13-15).

\section{Organ Damage/Failure (Neurological Complications)}

These include cerebrovascular accidents (strokes), transient ischemic attacks, silent infarcts and neurocognitive impairment.

Cerebrovascular accidents include infarctive stroke, hemorrhagic stroke and moyamoya. Infarctive stroke is an acute neurological syndrome resulting from impaired cerebral blood flow without evidence of hemorrhage lasting more than 24 hours. Hemorrhagic stroke is intracranial hemorrhage causing neurologic symptoms and signs. Moyamoya is abnormal vascular network ("puff of smoke" appearance) indicative of collateral circulation secondary to stenosis or 
occlusion of large cerebral arteries $(16,17)$. Transient ischemic attack is a brief episode of neurologic dysfunction caused by focal brain ischemia, with clinical symptoms typically lasting less than 1 hour, and without subsequent evidence of cerebral infarction $(16,18)$. Silent cerebral infarcts are changes on MRI of brain consistent with infarction without associated history of neurologic symptoms or abnormal neurological exam $(16,19)$.

Neurocognitive impairment is defined by the presence of abnormal non verbal function assessed by the Wechsler Adult Intelligence Scale III Performance IQ Index in adult patients with sickle cell anemia who are neurologically asymptomatic. This impairment is most likely secondary to cerebral hypoxemia undetectable by standard neuroimaging studies $(20,21)$.

Ophthalmologic Complications

The most important and serious ophthalmologic complications of sickle cell disease include the following: proliferative sickle retinopathy which are neovascular fronds that emerge from the retinal vasculature at the interface of perfused and non perfused retina in response to vascular growth factors produced by ischemic retina. The neovascular tissue is predisposed to hemorrhage and vitreoretinal traction forces. Although these pre retinal neovascular formations, which may resemble and are called sea fans, are bright red when viable, they appear white when autoinfarcted or caused to involute by laser photocoagulation (22).

Retinal detachment: separation of the retina from the choroid and eye wall due to holes in the retina and traction on the retina by vitreous bands and condensed preretinal membranes (usually as sequelae of proliferative sickle retinopathy). Retinal detachment is the most severe complication (Stage V) of proliferative sickle retinopathy (23).

Vitreous hemorrhage: bleeding into the vitreous cavity caused by mechanical stress (from trauma or normal vitreous movement) on the delicate neovascular fronds growing from the retina into the vitreous chamber. Vitreous hemorrhage is a severe complication of proliferative sickle retinopathy (24).

\section{Pulmonary Complications}

Acute chest syndrome is an acute illness characterized by fever and/or respiratory symptoms, accompanied by a new pulmonary infiltrate on chest X-ray $(25,26)$. Pulmonary hypertension is an elevation of pulmonary arterial systolic pressure (PASP) $(>25 \mathrm{mmHg}$ at rest or $>30 \mathrm{mmHg}$ with exercise). Cor pulmonale is a term used to describe those with end-stage pulmonary hypertension (27).

\section{Renal Complications}

Acute renal failure is characterized by an abrupt decline in renal function resulting in an inability to excrete metabolic wastes and maintain proper fluid and electrolyte balance $(28,29)$. Hematuria is presence of red blood cells in the urine, due to acute renal papillary necrosis, urinary tract infection, and less commonly by glomerulonephritis, obstruction, analgesic toxicity, mycobacterial infection, nephrolithiasis, tumor (renal cell carcinoma or medullary cell 
carcinoma), arterio-venous malformations, and vasculitis (30).

Priapism is a painful, persistent, unwanted erection of the penis (31). Proteinuria is any glomerular disorder associated with protein loss in the urine greater than $100 \mathrm{mg} / \mathrm{m} 2 /$ day (30).

Chronic renal failure is an irreversible and usually progressive reduction in renal function in which both kidneys have been damaged to the extent that they are unable to adequately remove the metabolic products from the blood and regulate the body's electrolyte composition and acidbase balance. End stage renal disease (ESRD) is the final stage in chronic renal insufficiency and, by definition, requires dialysis or renal transplantation to prevent death (32).

\section{Hepatobiliary Complications}

Hepatic sequestration is sequestration of red blood cells in hepatic sinusoids, leading to liver enlargement and decreased $\underline{\mathrm{Hb}}$ concentration by $\geq 2 \mathrm{~g} / \mathrm{dL}$ from baseline with reticulocytosis, without other explanation and liver enlargement of $\geq 3 \mathrm{~cm}$ for children and $\geq 5 \mathrm{~cm}$ for adults (from previous physical examination) without other explanation $(33,34)$.

Intrahepatic cholestasis is intrahepatic obstruction of bile formation or flow leading to hyperbilirubinemia. In sickle cell disease, this syndrome may occur in the context of hepatic sequestration with the addition of striking hepatic dysfunction. With marked increase in direct bilirubin ( $>50 \%$ of total) compared to baseline and absence of extrahepatic biliary system obstruction and absence of evidence of marked accelerated hemolysis (35).

\section{Musculoskeletal/Dermatologic Complications}

Dactylitis (hand-foot syndrome) is inflammation caused by ischemia/infarction of bone and/or bone marrow of the hands and/or feet, resulting in swelling, redness, and pain in affected areas. One of the earliest manifestations of sickle cell disease, dactylitis is seen primarily in children from 6 months to 3 years of age, and generally does not occur beyond 5 years of age, due to the lack of hematopoietic marrow activity in the hands and feet (36).

Avascular necrosis (AVN) is a condition resulting in dead bone tissue due to an interruption in blood supply, most likely as a result of vaso-occlusion. Bones near a joint, especially the hip, are primarily affected. Avascular necrosis is also referred to as aseptic necrosis, osteonecrosis, or ischemic necrosis of the bone $(36,37)$.

Leg ulcers are ulceration of the skin and underlying tissues of the lower extremities, especially the medial or lateral surfaces of the ankles. Trauma, infection, and severe anemia may predispose patients to ulcer formation $(38,39)$.

\section{CONCLUSIONS}

Having definitions of the complications of sickle cell disease based on available evidence in the literature and on the experience of hematologists in the field will improve future communications among clinical and basic scientists in the field. It is hoped that these preliminary definitions will 
be revised and refined regularly as on-going research and controlled clinical trials in sickle cell disease provide a better quality of evidence than what is available at the present.

\section{REFERENCES}

1. Ballas SK, Lieff S, Benjamin LJ, et al., Investigators, Comprehensive Sickle Cell Centers. Definitions of the phenotypic manifestations of sickle cell disease. Am J Hematol. 2010;85(1):6-12.

2. DeBaun, MR. Finally, a consensus statement on sickle cell disease manifestations: a critical step in improving the medical care and research agenda for individuals with sickle cell disease. Am J Hematol. 2010;85(1):1-2.

3. Bookchin RM, Nagel RL, Ranney HM. Structure and properties of Hemoglobin CHarlem, a human hemoglobin variant with amino acid substitutions in 2 residues of the $\beta$ polypeptide chain. J Biol Chem. 1967;242(2):248-255.

4. Williams GC. Pleiotropy, natural selection, and the evolution of senescence. Evolution. 1957;11(3):398-411.

5. Powars D, Hiti A. Sickle cell anemia. $\beta^{\mathrm{S}}$ gene cluster haplotypes as genetic markers for severe disease expression. Am J Dis Child. 1993;147(11):1197-1202.

6. Robertson KD, Wolffe AP. DNA methylation in health and disease. Nat Rev Genet. 2000;1(1):11-19.

7. Ballas SK. Pain management of sickle cell disease. Hematol/Oncolo Clin Am. 2005;19(5):785-802.

8. Zimmerman SA, Davis JS, Schultz WH, Ware RE. Subclinical parvovirus B19 infection in children with sickle cell anemia. J Pediatr Hematol Oncol. 2003;25(5):387-389.

9. Ballas SK, Marcolina MJ. Hyperhemolysis during the evolution of uncomplicated acute painful episodes in patients with sickle cell anemia. Transfusion. 2006;46(1):105-110.

10. Powell RW, Levine GL, Yang YM, Mankad VN. Acute splenic sequestration crisis in sickle cell disease: early detection and treatment. J Pediatr Surg. 1992;27(2):215-219.

11. Pearson HA, Gallagher D, Chilcote R, et al. Developmental pattern of splenic dysfunction in sickle cell disorders. Pediatrics. 1985;76(3):392-397.

12. Johnson CS. Arterial blood pressure and hyperviscosity in sickle cell disease. Hematol Oncol Clin North Am. 2005;19(5):827-837.

13. Ballas SK. Iron overload is a determinant of morbidity and mortality in adult patients with sickle cell disease. Semin Hematol. 2001;38(Suppl 1., 1):30-36.

14. Karam LB, Disco D, Jackson SM, et al. Liver biopsy results in patients with sickle cell disease on chronic transfusions: poor correlation with ferritin levels. Pediatr Blood Cancer. 2008;50(1):62-65.

15. St Pierre TG, Clark PR, Chua-Anusorn W, et al. Noninvasive measurement and imaging of liver iron concentrations using proton magnetic resonance. Blood. 2005;105(2):855-861.

16. Ohene-Frempong K, Weiner SJ, Sleeper LA, et al. Cerebrovascular accidents in sickle cell disease: rates and risk factors. Blood. 1998;91(1):288-294.

17. Dobson SR, Holden KR, Nietert PJ, et al. Moyamoya syndrome in childhood sickle cell disease: a predictive factor for recurrent cerebrovascular events. Blood. 2002;99(9):3144-3150.

18. Albers GW, Caplan LR, Easton JD, et al.; TIA Working Group. Transient ischemic attack—proposal for a new definition. N Engl J Med. 2002;347(21):1713-1716.

19. DeBaun MR, Derdeyn CP, McKinstry RC III. Etiology of strokes in children with sickle 
cell anemia. Ment Retard Dev Disabil Res Rev. 2006(3);12:192-199.

20. Vichinsky EP, Neumayr LD, Gold JI, et al.; Neuropsychological Dysfunction and Neuroimaging Adult Sickle Cell Anemia Study Group. Neuropsychological dysfunction and neuroimaging abnormalities in neurologically intact adults with sickle cell anemia. JAMA. 2010;303(18):1823-1831.

21. Ballas SK. Neurocognitive complications of sickle cell anemia in adults. JAMA. 2010;303(18):1862-1863.

22. Goldberg MF. Classification and pathogenesis of proliferative sickle retinopathy. Am J Ophthalmol. 1971(3);71:649-665.

23. Brazier DJ, Gregor ZJ, Blach RK, Porter JB, Huehns ER. Retinal detachment in patients with proliferative sickle cell retinopathy. Trans Ophthalmol Soc UK. 1986;105 (Pt. 1):100-105.

24. Dana MR, Werner MS, Viana MA, Shapiro MJ. Spontaneous and traumatic vitreous hemorrhage. Ophthalmology. 1993;100(9):1377-1383.

25. Vichinsky EP, Neumayr LD, Earles AN, et al. Causes and outcomes of the acute chest syndrome in sickle cell disease. National Acute Chest Syndrome Study Group. N Engl J Med. 2000;342(25):1855-1865.

26. Vichinsky EP, Styles LA, Colangelo LH, Wright EC, Castro O, Nickerson B. Acute chest syndrome in sickle cell disease: clinical presentation and course. Cooperative Study of Sickle Cell Disease. Blood. 1997;89(5):1787-1792.

27. Gladwin MT, Sachdev V, Jison ML, et al. Pulmonary hypertension as a risk factor for death in patients with sickle cell disease. N Engl J Med. 2004;350(9):886-895.

28. Bellomo R, Ronco C, Kellum JA, Mehta RL, Palevsky P; Acute Dialysis Quality Initiative workgroup. Acute renal failure-definition, outcome measures, animal models, fluid therapy and information technology needs: the Second International Consensus Conference of the Acute Dialysis Quality Initiative (ADQI) Group. Crit Care. 2004;8(4):R204-R212.

29. Lameire N, Van Biesen W, Vanholder R. Acute renal failure. Lancet 2005;365(9457):417-430.

30. Johnson C. Renal complications of the sickle cell diseases. Hematology. Am. Soc.

Hematol. Educ. Program. 1999:44-50.

31. Rogers ZR. Priapism in sickle cell disease. Hematol Oncol Clin North Am. 2005;19(5):917-928.

32. West MS, Wethers D, Smith J, Steinberg M. Laboratory profile of sickle cell disease: a cross-sectional analysis. The Cooperative Study of Sickle Cell Disease. J Clin Epidemiol. 1992;45(8):893-909.

33. Banerjee S, Owen C, Chopra S. Sickle cell hepatopathy. Hepatology. 2001;33(5):10211028.

34. Hatton CS, Bunch C, Weatherall DJ. Hepatic sequestration in sickle cell anaemia. Br Med J (Clin Res Ed). 1985;290(6470):744-745.

35. Shao SH, Orringer EP. Sickle cell intrahepatic cholestasis: approach to a difficult problem. Am J Gastroenterol. 1995:90(11):2048-2050.

36. Almeida A, Roberts I. Bone involvement in sickle cell disease. Br J Haematol. 2005;129(4):482-490.

37. Powars DR. Sickle cell anemia and major organ failure. Hemoglobin. 1990;14(6):573598.

38. Halabi-Tawil M, Lionnet F, Girot R, Bachmeyer C, Lévy PP, Aractingi S. Sickle cell leg ulcers: a frequently disabling complication and marker of severity. Br J Dermatol. 
2008;158(2):339-344.

39. Koshy M, Entsuah R, Koranda A, et al. Leg ulcers in patients with sickle cell disease. Blood. 1989;74(4):1403-1408. 
TABLE 1 Complications of Sickle Cell Disease

\begin{tabular}{|l|l|l|}
\hline Hemolytic Anemia and Its Sequelae & \multicolumn{1}{|c|}{ Pain Syndromes } & \multicolumn{1}{|c|}{ Complications Due to Organ Damage/Failure } \\
\hline Aplastic episode & Sickle cell pain (acute painful crisis) & Neurological complications \\
Hyperhemolysis & Acute multi-organ failure & Ophthalmological complications \\
Acute splenic sequestration & Neuropathic pain & Pulmonary complications \\
Intrasplenic Hemorrhage & Iatrogenic pain & Renal/genitourinary complications \\
Transfusion related complications & & Gastrointestinal/hepatobiliary complications \\
$\bullet \quad$ immune hemolysis & & Muscular/skeletal/skin complications \\
$\bullet \quad$ RBC antibody sensitization & & \\
$\bullet \quad$ transfusional hemosiderosis & & \\
& & \\
\hline
\end{tabular}

